\title{
ESTRUTURA POPULACIONAL DE PALAEMON PANDALIFORMIS (CARIDEA: PALAEMONIDAE) NA REGIÃO ESTUARINA DO RIO RIBEIRA DE IGUAPE, IGUAPE, SÃO PAULO
}

\author{
Bertini, G. ${ }^{1,}$; Freitas, D.F.B. ${ }^{1}$; Rodrigues, M.M. ${ }^{1}$ \& Ribeiro, C.C. ${ }^{1}$ \\ ${ }^{1}$ Universidade Estadual Paulista (UNESP), Campus Registro, Laboratório de Biologia e Cultivo de Crustáceos \\ (LABCRUST). \\ *Autor correspondente: gibertini@ registro.unesp.br
}

Palaemon pandaliformis é um camarão carídeo de pequeno porte, encontrado em ambientes de água salobra e salgada de regiões tropicais e subtropicais, constituindo um importante membro das comunidades bentônicas. Contudo, existem poucos estudos disponíveis sobre essa espécie no litoral sul do estado de São Paulo. Dessa forma, o presente trabalho buscou ampliar tais informações, enfocando na distribuição de frequência dos indivíduos em classes de tamanho, período reprodutivo e razão sexual. As coletas foram realizadas mensalmente no período de janeiro/14 a junho/15 na região estuarina do Rio Ribeira de Iguape, Iguape, SP. Os animais foram obtidos por meio de peneira de malha fina ( $5 \mathrm{~mm}$ entre nós) e armadilhas do tipo covo. Os camarões coletados foram mensurados na região do comprimento da carapaça (CC) e sexados com base na presença do apêndice masculino. Diferenças de tamanho (CC) entre machos e fêmeas foram analisadas pelo teste $t$. A razão sexual foi calculada para o total de indivíduos, bem como ao longo das estações amostradas, e desvios da proporção 1:1 foram verificados pelo teste binomial. Foram analisados 1.926 indivíduos, sendo 968 machos, 720 fêmeas e 238 ovígeras. Foram obtidas 9 classes de tamanho com amplitude $0,7 \mathrm{mmCC}$, sendo a classe de 4,8 a 5,5mmCC a mais representativa com 469 indivíduos. Os machos apresentaram tamanho médio de 4,93 $\pm 1,03 \mathrm{~mm}$ e as fêmeas de 5,25 $\pm 1,32 \mathrm{~mm}$. As fêmeas foram estatisticamente maiores que os machos $(t=11,96, p<0,0001)$, fato comumente observado para espécies em que os machos não defendem as fêmeas durante a cópula, como $P$. pandaliformis. As fêmeas ovígeras foram encontradas durante o ano todo, apresentando reprodução contínua, com pico na primavera, reduzindo a abundância no decorrer das demais estações, provavelmente para recuperação gonadal após intenso período reprodutivo. A razão sexual total não apresentou desvios significativos da proporção de 1:1 $(p=0,41)$. Em relação às estações do ano, no outono foi detectado desvio significativo para os machos $(p<0.001)$, enquanto que no inverno para as fêmeas $(p<0,001)$. Tais diferenças podem estar relacionadas com as diferentes taxas de crescimento e de mortalidade entre os sexos que levam a um desvio da proporção de 1:1. O presente estudo reuniu informações importantes sobre a estrutura populacional de $P$. pandaliformis no Rio Ribeira de Iguape, sendo tais informações de grande importância para o conhecimento da biologia populacional dessa espécie.

Palavras-chave: razão sexual, reprodução, Vale do Ribeira. 